\title{
Current Status of Prevalence, Possible Control and Risk Factors Associated with Porcine Cysticercosis from Endemic Countries in Africa
}

\author{
Seria Masole Shonyela ${ }^{1,2}$, Guilian Yang1, Chunfeng Wang ${ }^{1}$ \\ ${ }^{1}$ College of Animal Science and Technology, Jilin Provincial Engineering Research Center of Animal Probiotics, Jilin Agricultural \\ University, Changchun, China \\ ${ }^{2}$ Ministry of Agriculture, Livestock and Fisheries, Dar es Salaam, Tanzania \\ Email: seria.masole@sacidas.org, yangguilian@jlau.edu.cn,wangchunfeng@jlau.edu.cn
}

How to cite this paper: Shonyela, S.M., Yang, G.L. and Wang, C.F. (2018) Current Status of Prevalence, Possible Control and Risk Factors Associated with Porcine Cysticercosis from Endemic Countries in Africa. World Journal of Vaccines, 8, 53-80. https://doi.org/10.4236/wjv.2018.83006

Received: June 21, 2018

Accepted: August 24, 2018

Published: August 27, 2018

Copyright (C) 2018 by authors and Scientific Research Publishing Inc. This work is licensed under the Creative Commons Attribution International License (CC BY 4.0).

http://creativecommons.org/licenses/by/4.0/

\section{Open Access}

\begin{abstract}
Porcine cysticercosis (PC) caused by Taenia solium larvae is continuing being an important zoonotic neglected disease in many developing countries, is responsible for severe health disorders such as seizures and death in human and it poses a serious public health risk. In general estimated prevalence for porcine cysticercosis by Ag-ELISA was 29.7\% (95\% CI [4.8 - 58.2]), by EITB was $24.7 \%$ (95\% CI [9.2 - 38.2]), by Tongue examination was $9.4 \%$ (95\% CI [0.2 13.2]), and by postmortem examination was $15 \%$ (95\% CI [0.2 - 27.4]). Average seroprevalence of human cysticercosis by circulating antibody detection (Ab-ELISA) was ranged from $1.3 \%$ to $45.3 \%$. Average seroprevalence of human cysticercosis by circulating $T$. solium antigen detection (Ag-ELISA) was ranged from $4.6 \%$ to $11.9 \%$. Average seroprevalence of human cysticercosis by EITB was ranged from $6.9 \%$ to $16.7 \%$. Average prevalence of human cysticercosis by CT scan was ranged from $23.2 \%$ to $54.6 \%$. A fundamental factor in the occurrence of infections in most of the article was lack of health education to the community on $T$. solium, cysticercosis and taeniasis complex as the key towards control and eradication. The major causal factors of the disease occurrence were free roaming pigs and poor sanitary conditions.
\end{abstract}

\section{Keywords}

Taenia solium Cysticercosis, Prevalence, Risk Factors, Pig Management, Africa

\section{Introduction}

Porcine cysticercosis is an infection of pigs with the larval form of Taenia solium [1]. Pig production is an important economic activity to many poor families in 
developing countries [2] [3] [4] [5] [6] (Wilson, 2013). However, T. solium cysticercosis is being reported in these countries resulting in both agricultural and public health impacts [7]-[15]. The parasite causes taeniosis in human, who is the definitive host and cysticercosis in pigs which are principal intermediate hosts. Human being acquires taeniosis following ingestion of raw or undercooked pork infected with viable $T$. solium cysticerci [16] [17] [18]. The human being also can develop cysticercosis following accidental ingestion of $T$. solium eggs. Lodging of cysticerci of $T$. solium in the brain results in neurocysticercosis (NCC), one of the most important neurological parasitoses in human and the main preventable cause of acquired epilepsy in endemic areas [12] [19]. Neurocysticercosis is now recognized as an important public health problem in both developing and developed countries [3]. The study area consisted of 54 countries. The total population of pigs estimated in Africa in 2013 was $33,465,868$, which was approximately $3.4 \%$ of the world pig population estimate $977,274,246$ of 2013 [20]. Out of the Africa regional pig population, approximately $0.23 \%$, $6.07 \%, 41.3 \%, 17.3 \%$, and $35.1 \%$ were reared in the northern countries, southern, western, central, and eastern Africa respectively.

Porcine cysticercosis has been reported in many sub-Saharan countries with prevalence rates as high as $18 \%$ to $64 \%$ [13] [21] [22] [23] [24] [25]. In East African countries, the prevalence of cysticercosis infection among pigs in a number of areas reported being approximately 20\% [13] [26] [27] [28]. Endemicity of $T$. solium cysticercosis in developing countries have been associated with general poverty, free-ranging of pigs, poor sanitary conditions and poor knowledge about the parasite [13] [27] [29]-[34]. In addition, home slaughters of pigs without inspection, and inadequate pork cooking before consumption were also found to be responsible for the reported prevalence [26].

In Africa pig keeping is the common and free-range type of pig management which is practiced [35]. This review investigated the prevalence of porcine cysticercosis, distribution, possible control of disease and risk factors associated with T. solium cysticercosis transmission in Africa. The information is useful in planning parasite control measures in Africa to promote economic development through pig production.

\section{Methods}

\subsection{Sites for Review Study}

The search of the literature for this review was well organized pertaining to the prevalence of porcine cysticercosis and risk factors for T. solium in the district, country and regionally based studies carried out in endemic countries in Africa also few studies about human cysticercosis or taeniasis. And it was performed on a sequentially arranged material of literature published with year restriction from consist of; seventeen "17" countries eastern Africa, sixteen "16" countries western Africa, nine "9" countries central Africa, seven "7" countries northern Africa and five " 5 " countries southern Africa. 
(https://www.reference.com/geography/many-countries-africa-6d064c6831667ac 9) or Google search just by typing how many countries are in Africa.

\subsection{Techniques/Method of Study Selected}

This review the search and writing were performed from March $8^{\text {th }} 2017$ until August $31^{\text {st }}$ 2017. Literature Selection was well thought out to both techniques, in view of the fact that; both techniques have an advantage and disadvantages for the disease diagnosis. For this review to have excellent data, the search paid attention lying on the articles in which data was accomplished by means of the following methods and procedures: The search focused on data obtained from $T$. solium, Epidemiological survey, Tongue and postmortem examination, circulating antibody and antigen that detected by Enzyme-linked Immunoelectrotransfer Blot (EITB) or by enzyme-linked immunosorbent assay [36].

1) Antemortem (tongue palpation and small incision) and post mortem meat inspection were widely used in Africa for diagnosis of porcine cysticercosis. However on the other hand, both methods are limited on sensitivity [37].

Antemortem by tongue examination/palpation to check for the presence of cysticerci. Because the prevalence of pigs with Tongue examination/palpation do relate to the prevalence of heavy infection. The data on this method were from [14] [26] [38] [39].

2) Postmortem examination or meat inspection. Many research conducted to assess the presence of $T$. solium cysticerci by opening the predilection sites [26] [27] [28] [31] [34] [40]-[47]. Enzyme Linked Immunosorbent Assay detecting circulating antigens from the $T$. solium metacestode (B158/B60 Ag-ELISA or HP10 Ag-ELISA).

The B158/B60 Ag-ELISA the reported sensitivity to detect circulating antigens produced by $T$. solium metacestodes in pigs ranges from $85 \%$ to $90 \%$ and the specificity was from $92 \%$ to $96 \%$ (from [30] [32] [47]-[57]).

3) Enzyme-linked Immuno electro transfer Blot (EITB) [58].

The reported EITB has a sensitivity ranging from $97 \%$ to $98 \%$ and a specificity ranging from 97 to $100 \%$ to detect circulating antibodies to T. solium in human serum (from [45] [58]-[63]).

4) Ab-ELISA, Ag-ELISA CT-scan and Coprology, for human Cysticercosis or taeniasis (from [50] [64]-[70]).

5) Risk factor for Porcine Cysticercosis, Taenia solium, and Taeniasis.

6) Porcine cysticercosis reports from the World Organisation for Animal Health.

The understandable data about prevalence of porcine cysticercosis was collected to the accessible selected articles and there was no limitations meant for the diagnostic technique was made. Although it was well known that the porcine cysticercosis or taeniasis data would be biased by the technique used because of the difference of prevalence's results found such as Seroprevalence and other methods have large variations in their diagnostic performances. Ag-ELISA has 
been reported to have high sensitivity ranging between $76.3 \%$ and $86.7 \%$ and a specificity ranging between $84.1 \%$ and $98.9 \%$ in pigs in Tanzania, Kenya, South Africa, Mozambique, Madagascar, Zambia and West Cameroon [23] [40] [63] [71] [72] [73] [74] [75].

\subsection{Language}

The restriction of the language was applied the considered languages was English. This means the article were not considered when was written in a language other than English spoken or understood by the authors of this review.

\subsection{The Selected Databases for This Study}

1) Elsevier

(https://www.journals.elsevier.com/the-lancet-infectious-diseases/),

2) Veterinary Parasitology (http://www.sciencedirect.com/science/journal/),

3) PubMed (http://www.ncbi.nlm.nih.gov/pubmed/).

As well Literature references that were found in appropriate articles of the above database were furthermore looked into to gather all acknowledged studies on incidence of $T$. solium for prevalence of porcine cysticercosis, or taeniosis. Furthermore we manually searched other databases that were appropriate articles for facilitating data that were not found with the above search strategy such as Google Scholar (http://www.google.com) and Baidu (http://www.baidu.com).

\subsection{Exploration of the Search}

Prevalence of porcine Cysticercosis and risk factor was the main topic or focus of the study. For that reason, more consideration was set to this aspect. A total of 378 articles were retrieved following quite a lot of searches by writing the terms/the topic or the subject matter in the major search bar of the web; the following search terms were: (Porcine cysticercosis in Africa, Swine Cysticercosis in Africa, Pig cysticercosis in Africa, Risk factor of Taenia solium in Africa, Neurocysticercosis in Africa, cellulosae in Africa, Taenia solium in Africa, Tapeworm in Africa, Taeniasis in Africa, Taeniosis in Africa, Taeni in Africa, and Cysticerc in Africa, And Prevalence of "Porcine or swine Cysticercosis in; Tanzania, Kenya, Uganda, Zambia, Mozambique, Malawi, Congo DRC, Rwanda, Burundi, South Africa, Zimbabwe, Algeria, Angola, Benin, Swaziland, Botswana, Burkina Faso, Morocco, Cameroon, Mali, Central African Republic, Chad, Cote d'Ivoire, Ivory Coast, Djibouti, Egypt, Libya, Equatorial Guinea, Eritrea, Ethiopia, Gabon, Gambia, Nigeria, Ghana, Guinea, Sierra Leone, Guinea-Bissau, Lesotho, Liberia, Madagascar, Mauritania, Namibia, Niger, Senegal, Somalia, South Sudan, Sudan, Togo, and Tunisia") for the period from 2001 to 2017.

In some database like Elsevier (https://www.journals.elsevier.com/the-lancet-infectious-diseases/) to achieve highest number of articles the terms pig, swine, porcine and countries names was excluded. 


\subsection{Selected Study}

All countries where the selected studies took place were visualized using Google map. In the beginning we assessed every title and abstract prior to assess the full document/text; Authors of articles where full-text were inaccessible were contacted to gather scientific publications associated to porcine cysticercosis in each country and some we used Sci Hub; to remove barriers. When an appropriate article was encountered, required information such as diagnostic method, Results (disease magnitude), and sample size was recorded when accessible.

Available information were collected from 89 study locations which the study sites were located in 19 countries across Africa that reported the prevalence of whether documented as porcine cysticercosis, human cysticercosis, neurocysicercosis, taeniosis, or Taenia solium was included whether it was diagnosed by the following protocols/methods; epidemiological survey (questionnaires, environmental studies, antemortem, postmortem), and serological examination, for human cysticercosis or taeniasis by Ab-ELISA, Ag-ELISA and Coprology. Other criteria were; random sampling method for selection of pigs in the study or number of sample size, and authors for all the articles used were cited. The most up to date literature was preferred.

\subsection{Excluded Study}

The studies that performed and published before the year 2001 was excluded, all repeated studies from the title selection in the same country was excluded, studies based on questionnaire only were excluded for porcine cysticercosis prevalence [76]. Also environmental only studies was excluded, Wrong parasite species e.g. [77], Studies performed in non-endemic countries or if based on experimental studies where location of infection could not be established, only clinical studies e.g. [37], Studies carried out for assessing laboratory tests performance, For human cysticercosis or taeniosisi Studies that focused on NCC only e.g. [15]. Articles written in languages other than those spoken or understood by all authors of this review some articles in west Africa countries was written in French e.g. [78], if full-text was not available (Figure 1).

\subsection{Data Collection}

The following topics/items were collected and opened in a data base as of all preferred article:

1) Author(s) For example; Seria M. Shonyela, Ernatus M. Mkupasi, Sikasunge C. Sikalizyo, Evance M. Kabemba, Helena A. Ngowi and Isaac Phiri,

2) Year the article was published 2017,

3) Country Tanzania,

4) Number of pigs for Ag-ELISA survey 330 ,

5) Number of Ag-ELISA positive detected cases 110,

6) Number of Pigs for Tongue palpation/examination/or Lingual palpation 698 , 


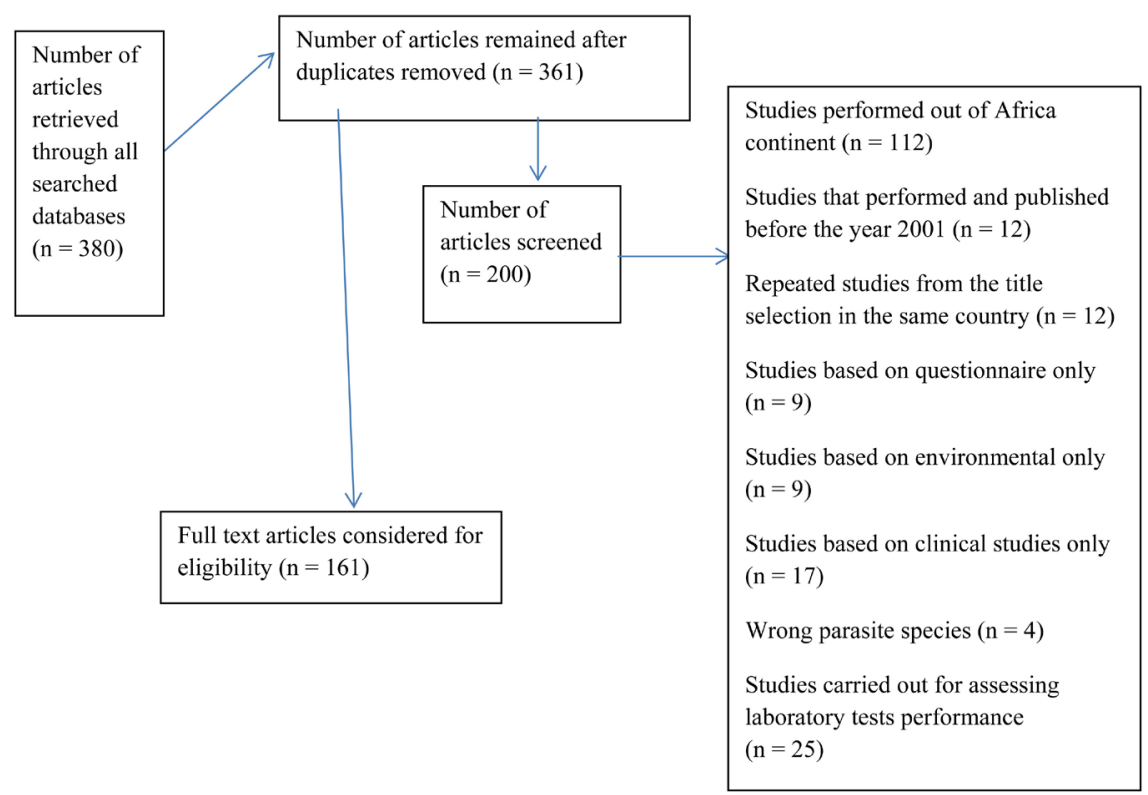

Figure 1. A flow chart for the inclusion process of literatures analyzed.

7) Number of Tongue palpation/examination/or Lingual palpation positive detected cases 44 ,

8) Number of pigs for EITB survey 0, number of EITB positive detected cases 0 but there were articles with the EITB diagnosis methods and positive cases,

9) Risk factors questionnaire survey was administered to a member of selected households to gather information on pig management and other potential factors that could explain the prevalence of PC in the area.

In addition, if the study was conducted and associated with an analysis lying on porcine cysticercosis or associated with human taeniasis, the prevalence and the method used to diagnose cysticercosis and taeniasis were as well collected.

\subsection{Statistical Analysis}

The averages of prevalences in each method were used to estimate general prevalences. We calculated the average Seroprevalence of circulating antigens $T$. solium, Seroprevalence for antibodies, the prevalence of Tongue examination, and postmortem in each country of Africa that was selected in this review. Also average of Ninety five\% Confidence Intervals $(95 \% \mathrm{CI}$ ) were calculated for all reported prevalence's. The significant differences in estimated prevalences were evaluated using their $95 \%$ confidence intervals. The variations in prevalence between the selected countries were well thought out to be statistically significant if their $95 \%$ confidence intervals do not extend beyond.

\section{Results}

\subsection{Country Selection and Study Selection}

Number of article selected from each country and the data found as it is shown in the Literature review (references) page and Table 1 respectively. First we read 
Table 1. Summery showing population of pig, prevalence of porcine cysticercosis recorded in each country in Africa from year 2001 to 2017.

\begin{tabular}{|c|c|c|c|c|c|c|}
\hline $\mathrm{S} / \mathrm{N}$ & Country & $\begin{array}{c}\text { Pig } \\
\text { Population }\end{array}$ & $\begin{array}{c}\text { Seroprevalence } \\
\text { (\%) }\end{array}$ & $\begin{array}{l}\text { Prevalence } \\
\text { (\%) Tongue } \\
\text { Examination }\end{array}$ & $\begin{array}{c}\text { Prevalence } \\
(\%) \text { by } \\
\text { Postmortem }\end{array}$ & References \\
\hline 1 & Algeria & 5000 & ND & ND & ND & [79] \\
\hline 2 & Angola & $2,603,365$ & ND & ND & 6.8 & [14] [79] \\
\hline 3 & Begnin & 414,000 & ND & ND & ND & [79] \\
\hline 4 & Botswana & 13,500 & ND & ND & ND & [79] \\
\hline 5 & Burkinafaso & $2,345,188$ & 36.05 & ND & 4.6 & [23] [50] [79] \\
\hline 6 & Burundi & 388,242 & ND & ND & $2-39$ & [14] \\
\hline 7 & Cape Verde & 84,559 & ND & ND & ND & [79] \\
\hline 8 & Cameroon & $1,750,000$ & $11-32.2$ & $4.2-26.6$ & 15.7 & $\begin{array}{l}{[14][59][63]} \\
{[79][80][81]}\end{array}$ \\
\hline 9 & $\begin{array}{c}\text { Central African } \\
\text { Republic }\end{array}$ & $1,000,000$ & ND & ND & ND & [79] \\
\hline 10 & Chad & 33,000 & ND & 6.8 & 25.7 & [14] [79] \\
\hline 11 & Comoros & ND & ND & ND & ND & ND \\
\hline 12 & Ivory Coast & 362,693 & ND & ND & ND & [79] \\
\hline 13 & $\begin{array}{l}\text { Democratic } \\
\text { Republic of } \\
\text { Congo }\end{array}$ & $1,050,000$ & $38.8-41.2$ & 5.5 & ND & $\begin{array}{c}{[23][50][79]} \\
{[82]}\end{array}$ \\
\hline 14 & Djibouti & ND & ND & ND & ND & ND \\
\hline 15 & Egypt & 10,600 & ND & ND & $12-40$ & [79] [83] [84] \\
\hline 16 & $\begin{array}{c}\text { Equatorial } \\
\text { Guinea }\end{array}$ & 6700 & ND & ND & ND & [79] \\
\hline 17 & Eritrea & ND & ND & ND & ND & ND \\
\hline 18 & Ethiopia & 33,000 & ND & ND & ND & [79] \\
\hline 19 & Gabon & 225,000 & ND & ND & ND & [79] \\
\hline 20 & Gambia & 4873 & 4.8 & 0.6 & & [79] [85] \\
\hline 21 & Ghana & 638,000 & ND & ND & 18.8 & [79] [86] [87] \\
\hline 22 & Guinea & 104,000 & ND & ND & ND & [79] \\
\hline 23 & Guinea-Bissau & 460,000 & ND & ND & ND & [79] \\
\hline 24 & Kenya & 432,979 & $4-43.3$ & $3-34.4$ & ND & $\begin{array}{c}{[3][27][31][35]} \\
{[40][79][88]} \\
{[89][90][91]}\end{array}$ \\
\hline 25 & Lesotho & 81,000 & ND & ND & ND & [79] \\
\hline 26 & Liberia & 292,000 & ND & ND & ND & [79] \\
\hline 27 & Libya & ND & ND & ND & ND & ND \\
\hline 28 & Madagascar & $1,500,000$ & 21.3 & ND & $2.3-4.6$ & [72] [79] [92] \\
\hline 29 & Malawi & $2,754,414$ & ND & ND & ND & [79] \\
\hline
\end{tabular}




\section{Continued}

\begin{tabular}{|c|c|c|c|c|c|c|}
\hline 30 & Mali & 77,594 & ND & ND & ND & [79] \\
\hline 31 & Mauritania & ND & ND & ND & ND & ND \\
\hline 32 & Mauritius & 14,500 & ND & ND & ND & [79] \\
\hline 33 & Morocco & 8000 & ND & ND & ND & [79] \\
\hline 34 & Mozambique & $1,800,000$ & $6-34.9$ & $5.1-12.7$ & ND & $\begin{array}{l}{[34][48][79]} \\
{[93][94][95]}\end{array}$ \\
\hline 35 & Namibia & 72,500 & ND & ND & ND & [79] \\
\hline 36 & Niger & 42,500 & ND & ND & ND & [79] \\
\hline 37 & Nigeria & $8,080,000$ & $9.6-46$ & ND & $3.2-14.4$ & $\begin{array}{c}{[46][79][96]} \\
{[97][98][99]} \\
{[100]}\end{array}$ \\
\hline 38 & $\begin{array}{l}\text { Republic of } \\
\text { Congo }\end{array}$ & 95,000 & ND & ND & ND & [79] \\
\hline 39 & Rwanda & $1,011,250$ & 20 & ND & 6.8 & [14] [66] [79] \\
\hline 40 & $\begin{array}{c}\text { Sao Tome and } \\
\text { Principe }\end{array}$ & 33,000 & ND & ND & ND & [79] \\
\hline 41 & Senegal & 386,000 & $6.4-13.2$ & 0.2 & ND & [79] [85] \\
\hline 42 & Seychelles & 55,500 & ND & ND & ND & [79] \\
\hline 43 & Sierra Leone & 55,000 & ND & ND & ND & [79] \\
\hline 44 & Somalia & 3700 & ND & ND & ND & [79] \\
\hline 45 & South Africa & $1,600,000$ & $28.2-64.4$ & 11.9 & & $\begin{array}{c}{[4][6][30][73]} \\
{[79][101]}\end{array}$ \\
\hline 46 & South Sudan & ND & ND & ND & ND & ND \\
\hline 47 & Sudan & ND & ND & ND & ND & ND \\
\hline 48 & Swaziland & 35,000 & ND & ND & ND & [79] \\
\hline 49 & Tanzania & 500,000 & $7.3-33.3$ & $7.3-16.9$ & $5.9-8.2$ & $\begin{array}{c}{[9][13][21][26]} \\
{[28][32][42]} \\
{[47][51][64]} \\
{[69][71][74]} \\
{[75][79]} \\
{[102]-[108]}\end{array}$ \\
\hline 50 & Togo & $1,000,000$ & ND & ND & ND & [79] \\
\hline 51 & Tunisia & 5500 & ND & ND & ND & [79] \\
\hline 52 & Uganda & 249,760 & $8.6-25.7$ & $6.5-12.9$ & 18.0 & $\begin{array}{c}{[25][79][89]} \\
{[109][110][111]} \\
{[112][113]}\end{array}$ \\
\hline 53 & Zambia & $1,098,951$ & $9.3-56.6$ & $2.2-20.6$ & 20.6 & $\begin{array}{c}{[12][33][65]} \\
{[79][114]-[119]}\end{array}$ \\
\hline 54 & Zimbabwe & 650,000 & $2.7-28.6$ & & 0.3 & [79] [117] \\
\hline & $\begin{array}{c}\text { TOTAL } \\
\text { ESTIMATE }\end{array}$ & $33,465,868$ & 24.3 & 7.21 & 21.6 & \\
\hline
\end{tabular}

about 378 articles about Taenia solium but, no more than 161 studies were included, since some data were too old to be included in this review. More than 2 
studies were selected from each country in Africa.

\subsection{Porcine Cysticercosis in Africa}

From the sixty eight (68) studies about prevalence of porcine cysticercosis of twenty endemic reported countries. Nine studies used both diagnostic methods; tongue/lingual palpation, Postmortem, and serological studies; Twenty three (23) studies used Ag-ELISA and Tongue/lingual palpation, Three (3) studies used Ag-ELISA and EITB, Four studies used only tongue/lingual palpation, Thirteen studies used only postmortem, Three (3) studies used only EITB, and fourteen studies used only Ag-ELISA.

The total number of selected article was one ninety. An average seroprevalence of porcine cysticercosis by circulating antigens detection was ranged from $4.8 \%$ to $50.25 \%$ while seroprevalence by antibodies detection was ranged from $10 \%$ to $33.3 \%$. Average Prevalence by tongue/lingual palpation or examination was ranged from $0.6 \%$ to $11.9 \%$. Average Prevalence by postmortem examination/meat inspection was ranged from $4.6 \%$ to $26 \%$ thorough descriptions of every study are specified as summery in Table 1.

By using the above results on Table 1 indicated that the estimated prevalence of porcine cysticercosis in Africa was low as there were no data or old data in some countries.

\subsection{Estimation of the Overall Porcine Cysticercosis Prevalence}

Average prevalence of porcine cysticercosis in each country based on Ag-ELISA was used to estimate an overall prevalence of porcine cysticercosis in the country except for those countries with no data based on Ag-ELISA were estimated according to methods used. The overall estimated prevalence's from endemic countries were; in Tanzania of $(22.2 \%$ (95\% CI [1.4\% - 42\%]) from twelve studies, in Zambia, of (24.32\% (95\% CI [1.2 - 47.3]) from eight studies, in Kenya of (22.9\% (95\% CI [1.9 - 43.5]) from seven studies, in Uganda of $(18.0 \%$ (95\% CI [0.8 - 46.9]) from six studies, in Mozambique, of (10\% (95\% CI [2.3 - 32.3]) from five studies, in Nigeria of (27.8\% (95\% CI [2.3 - 52]) from five studies, in Cameroon, of $(19.5 \%$ (95\% CI [2.2 - 46.4]) from three studies, in South Africa, of (50.2\% (95\% CI [4.6 - 68.4]) from three studies, in Democratic republic of Congo (DRC) of 39.6\% (95\% CI 2.1 - 61.3]) from two (2) studies, in Burkina Faso, of (36.05\% (95\% CI [2.8 - 42]) from two (2) studies, in Madagascar of $(21.3 \%$ (95\% CI [2.5 - 38.4]) from two (2) studies, in Egypt of (30\% (95\% CI [6.2. - 47.3]) from two (2) studies, in Angola of (6.8\% (95\% CI [2.7 - 8.2]) from one (1) study, in Chad of (25.7\% (95\% CI [2 - 30]) from one (1) study, in Burundi of 39\% (95\% CI [2 - 40]) from one (1) study, in Senegal of (13.2\% (95\% CI [0.1 - 17.3]) from one (1) studies, in Rwanda of (20\% (95\% CI [2.1 - 23]) from one (1) studies, in Zimbabwe, of (28.6\% (95\% CI [1.2 - 33.3]) from one (1) study. in Gambia of (4.8\% (95\% CI [0.2 - 8.2]) from one (1) study. study. in Ghana of $(18.8 \%(95 \%$ CI $[4-22.2])$ from one (1) study. 
In general Sixty eight (68) studies out of 183 articles estimated the prevalence of PC/T. solium as follows: 45 articles by Ag-ELISA were 29.7\%, 15 articles by EITB were $24.7 \%$ (95\% CI [4.8 - 54.7]), 44 articles by tongue examination were 9.4\% (95\% CI $[0.2 \%-40 \%]), 22$ articles by postmortem were $15 \%$ (95\% CI [0.2\% $-32 \%]$ ) as summarized in Table 2.

\subsection{Prevalence of Human Cysticercosis in Some Countries in Africa}

As summerised in Table 3, Twenty number of articles were included in this review for human cyaticercosis/taeniasis from ten countries from which; One (1) was studied for both methods (Ab-ELISA, Ag ELISA, EITB, and Coprology), Six (6) were studied for circulating antibody and antigen (Ab-ELISA and Ag-ELISA), Seven for only circulating antibody, One (1) was studied for only CT scan, and One (1) was studied for only Coprology.

Average seroprevalence of human cysticercosis by circulating antibody detection (Ab-ELISA) were ranged from $1.3 \%$ to $45.3 \%$, Average seroprevalence of human cysticercosis by circulating $T$. soliumantigen detection (Ag-ELISA) were ranged from $4.6 \%$ to $11.9 \%$. Average seroprevalence of human cysticercosis by EITB were ranged from $6.9 \%$ to $16.7 \%$. Average Prevalence of human cysticercosis by CT scan was ranged from $23.2 \%$ to $54.6 \%$ (Table 3 ).

\subsection{Risks Factors Associated with Active Human Cysticercosis}

According to the study in Zambia by Mwape and colleagues 2015 [118] demonstrated that Seropositivity was significantly positively related to age but not related to gender. cysticercus antigens increased significantly in individuals above the age of 30. But Copro-Ag positivity was not related to age or gender. Many studies showed that significantly higher sero-Ag to the age of 60 years. Previous studies have indicated higher levels of active infection in elderly people, may be

Table 2. Diagnostic tests used for the estimating prevalence of porcine cysticercosis in Africa were.

\begin{tabular}{|c|c|c|c|c|}
\hline Test & Disease & $\begin{array}{c}\text { Prevalence } \\
\%\end{array}$ & $\begin{array}{c}95 \% \\
\text { Confidence } \\
\text { interval }\end{array}$ & Reference \\
\hline $\begin{array}{c}\text { Ag-ELISA } \\
(\mathrm{B} 158 / \mathrm{B} 60) \text { and } \\
(\mathrm{HP} 10)\end{array}$ & $\begin{array}{c}\text { Porcine } \\
\text { cysticercosis }\end{array}$ & 29.7 & $0.8-62$ & $\begin{array}{c}{[3][9][14][21][23][28][31]} \\
{[32][33][35][40][59][71][72]} \\
{[73][75][99][101][105][108]} \\
{[110][112][116][117]} \\
{[119]-[124]}\end{array}$ \\
\hline EITB & $\begin{array}{c}\text { Porcine } \\
\text { cysticercosis }\end{array}$ & 24.7 & $4.8-54.7$ & [18] [30] [33] [34] [59] [101] \\
\hline Lingual examination & $\begin{array}{c}\text { Porcine } \\
\text { cysticercosis }\end{array}$ & 9.4 & $0.2-40$ & $\begin{array}{c}{[9][14][26][28][30][31][34]} \\
{[35][40][45][48][63][71][75]} \\
{[90][91][110][119][125]}\end{array}$ \\
\hline Post-mortem & $\begin{array}{c}\text { Porcine } \\
\text { cysticercosis }\end{array}$ & 15 & $0.2-32$ & $\begin{array}{c}{[26][40][41][72][94][99]} \\
{[107][126][127][128]}\end{array}$ \\
\hline
\end{tabular}


Table 3. Summery prevalence of human cysticercosis/taeniosis in Africa from few selected studies.

\begin{tabular}{|c|c|c|c|c|c|c|}
\hline Country & $\begin{array}{c}\text { Ab-ELISA } \\
(\%)\end{array}$ & Ag-ELISA \% & EITB (\%) & $\begin{array}{c}\text { CT SCAN } \\
(\%)\end{array}$ & $\begin{array}{c}\text { COPROLO } \\
\text { GY (\%) }\end{array}$ & References \\
\hline Zambia & 39.3 & 23.2 & ND & $4.1-24.5$ & 14.8 & [118] \\
\hline Burkina Faso & $1.3-10.3$ & 17 & ND & $\mathrm{ND}$ & ND & [19] [129] \\
\hline DRC & $6.3-23.4$ & ND & ND & 41.2 & ND & [3] \\
\hline Burundi & $20-40.8$ & 4.6 & 6.9 & ND & ND & [123] [130] \\
\hline Tanzania & $2.8-45.3$ & 11.9 & $14-16.7$ & $4-54.6$ & 5.2 & $\begin{array}{c}{[47][104][131]} \\
{[132]}\end{array}$ \\
\hline Egypt & 6.5 & & & & & [84] [133] \\
\hline Ghana & & ND & ND & ND & 13.15 & [86] \\
\hline Nigeria & $8.4-40.9$ & ND & $\mathrm{ND}$ & ND & ND & $\begin{array}{c}\text { [99] [134] [135] } \\
{[136][137]}\end{array}$ \\
\hline Mozambique & 8 & 15.5 & ND & 71.9 & ND & [15] \\
\hline Uganda & 9 & 15 & 13 & ND & ND & [138] \\
\hline Total range & $1.3-45.3$ & $4.6-11.9$ & $6.9-16.7$ & $23.2-54.6$ & $5.2-14.8$ & 16 \\
\hline
\end{tabular}

due to a lowered host immune response [22].

The study in Tanzania by Mwanjali and colleagues 2013 [47] revealed that being older age had high risk for seropositivity with human cysticercosis in the regression model, because they found that Ag-ELISA was higher in the age groups $36-45$ years $(\mathrm{OR}=2.5)$ and $46-60$ years $(\mathrm{OR}=2.6)$ as compared to young people $<25$ years. In contrast, human cysticercosis by Ab-ELISA in the regression model, the study demonstrated the risk for seropositivity that related to gender as was found to be significantly higher for males as compared to females and was related to family history as was found to be significantly higher for people using an unsafe source of water.

\subsection{Continent Distributions of the Endemic Countries Where Studies Were Held}

Prevalence of Porcine Cysticercosis, Human Taeniosis/Cysticercosis data reported using different diagnostic techniques, of the checked information; Forty three (43) studies were from nine countries in east Africa, Three (3) studies were from one (1) country in Southern Africa, Ten studies were from five countries in west Africa, Two (2) studies were from one (1) country in Northern Africa, Seven studies were from four (4) countries in Central Africa. In these studies, clear prevalence on porcine cysticercosis varied from $0.2 \%$ to $56 \%$ as results shown in Table 1.

\subsection{Risk Factors for Porcine Cysticercosis and Human Cysticercosis in Africa Countries}

Of the 161 articles selected out of it 72 Articles were reported risk factors for the 
presence of Taenia solium as causes of porcine Cysticercosis and human cysticercosis. The management systems used by pig farmers in Africa are dogged by an assortment of causes as well as the source of feed, Deficient of financial resource for animal houses, feeding and health concern obligations [8] [13] [30] [70] [76] [88] [89] [90] [120] [125] [139] [140] [141] [142]. The famous risk factors for the presence of porcine Cysticercosis and human taeniosis/cysticercosis were: Inadequate research attention and investments in pig production [76], Free range pig rearing (Penrith et al., 2007), insufficient latrines or poor use of latrines because of foul odors, flies, latrine deluging and lack of privacy as no an exceptional concern to be given to construction of latrines to be easy to people with disabilities, old people and children [13] [33] [104] [114] [133], insufficiency sanitary for example Poor sanitation carried out in slaughterhouses [42] [46] [143] [144] health education to the community [104] [143] [145]. Keeping pig for long time as increased risk with age [31] [35] [57] [59] [74] [98] [107] [120] [146] lack of potable water and poor personal and house hygiene [15] undercooked pork consumption, Free-roaming of pigs and Poor sanitary conditions acknowledged as significant risk factors for porcine cysticercosis are habitually associated to the low level of education stuck between the pig farmers that limits their knowledge on the management of pigs [30] [125]. Almost absolute unawareness of the $T$. solium life cycle concerning pigs and humans (taeniosis and neurocysticercosis) has been reported within studies carried out in Africa [33] [34] [59] [147]. Good numbers of farmers in endemic areas are familiar with on the subject of the cysts in infected pigs, although a small number of farmers are conscious of how pigs acquire the infection [32] [33] [47] [57] [108] [147] [148].

In rural areas pig production can be classified into three main categories [103] scavenging/free range system where the pig finds most of its own food, and semi-intensive and intensive systems where the majority of the food consists of domestic kitchen waste. About $90 \%$ of pigs are reared under scavenging/free range and semi-intensive in Western and Central African countries [13] [15] [37] [60] [149]. In these pig production systems, poor sanitary conditions play an important role in the circulation of T. solium infection [14]. A free-range production system for pigs combined with open field defecation by humans are the conditions in which the animals can gain access to human faeces [28] [32] [33] [75] [146] [150]. Intensive pig production systems do not always eliminate $T$. solium transmission because in Cameroon for instance some farmers are known to defecate directly in the pigsties [151]. The characteristics of traditional pig production systems favoring $T$. solium taeniosis/cysticercosis in Eastern and Southern African countries are largely similar to those reported in West and Central Africa [9] [27] [30] [32] [71] [125]. Pig keeping is predominantly of the smallholder, traditional type, characterized by a free-range management system [12] [30] [72] [114] [125] [152] South Africa and Ethiopia. 


\section{Discussion}

Generally, pork or pig-meat products are consumed in Africa, but in Islamic countries it is prohibited and there were few or no data in Islamic countries. Many counties of Africa Continent well liked keeping pigs, though, there has been no study that has evidently described the outline overall status of porcine cysticercosis and overall clear outline of pig production in Africa continent [8] [153]. In actuality, porcine or swine cysticercosis is the result of pig ingesting Taenia solium egg coming from human feces containing tapeworm egg that may perhaps have acquired the cyst from pork meat either locally produced or transported from other endemic regions [154] [155] [156] [157]. For that reason this review was important in order to understand the currency prevalence of porcine cysticercosis in the continent as well as pig production, in view of the fact that, Africa is one of the continents where the full cycle of $T$. solium is taking place because of the favorable environmental situation or behavioral conditions enhancing egg distribution and survival and also because of poverty, which holds back application of efficient control measures for the parasite, because the presence of circulating antigens at a population level is the outcome of viable cysticerci in pigs.

The information presented in this review assessed a number of literatures details of the current status of porcine cysticercosis in each country of Africa based on available scientific literature on: tongue/lingual palpation, postmortem and seroprevalence. The outcome of this review allowed us to estimate the prevalence of porcine cysticercosis and introduction to the parasite in endemic districts of different countries in Africa. Porcine cysticercosis, Taenia soliumor human cysticercosis/taeniosis were recognized in eighty nine (89) districts in nineteen (19) African countries lying on the literature search. At the moment we are familiar with the cysticercosis caused by Taenia solium metacestode, as one of the major public health diseases, which infects pigs and plays an important role in human taeniosis and cysticercosis. This review also points out that a number of factors associated with etiology and persistence of $T$. solium cysticercosis exist in pig production systems in Africa.

In this review immunodiagnostic tests such as Ag-ELISA and EITB are found sensitive and specific and showed as the best method of detecting the cysticercosis both in pigs and human but immunodiagnostic tests are not simply available in every country because both require access to laboratory with appropriate apparatus and training staff. Therefore antemortem tongue palpation and postmortem meat inspection are in general used in Africa meant for diagnosis of porcine cysticercosis in any environment and by any who know the Taenia Soliumcyst even animal slaughters or butchery. However on the other hand, both these two methods are limited on sensitivity.

The general estimated prevalence of porcine cysticercosis in Africa was (24.3\%), and of human taeniosis/cysticercosis was (37.3\%). Although some countries had no data or were not significantly different, Table 1 . The estimated 
prevalence of porcine cysticercosis by tongue examination was higher in endemic areas of Kenya, Zambia, Tanzania and Uganda (34.4\%, 20.6\%, 16.9\%, 12.9\%) compared to Democratic Republic of Congo, Senegal, Gambia, and South Africa $(5.5 \%, 0.2 \%, 0.6 \%$ and $11.9 \%)$, respectively, despite the fact that this difference was not statistically significant due to number of studies was higher and more current in Tanzania, Zambia, Kenya and Uganda than DRC, Senegal, Gambia, and South Africa. Once studied in detail, all the Tanzanian studies except two showed a higher prevalence of porcine cysticercosis than the studies in South Africa. The prevalence of Tongue examination, Postmortem and circulating antigens reported in Kenya, Zambia, Tanzania South Africa, Mozambique and Uganda ranged from $3 \%$ to 56.6\%, [12] [13] [30] [40] [48] [71] [110] while the prevalence in, Nigeria, Cameroon, Madagascar, Gambia and Senegal ranged from $3 \%$ to $25 \%$, [35] [59] [72] [158], excluding one study from Nigeria reporting a prevalence of $46 \%$ [159]. The figures observed in Table 3 demonstrated big variations in prevalence of porcine cysticercosis between using Tongue examination, Postmortem, and sero-prevalence by antigen and antibodies detection.

Studies from the South Africa, Zambia, and Democratic Republic of Congo (DRC) [12] [23] [30] [73], revealed exceptionally high prevalence statistics of circulating antigens and antibodies not recorded in whichever other part of the Africa (57\%, 56.6\% and 41.2\%, respectively). The statistics recommend a higher incidence of porcine cysticercosis in Tanzania, Kenya, Uganda, South Africa, Zambia, Mozambique and Democratic Republic of Congo (DRC), at the same time as compare to Senegal, Gambia, Zimbabwe, Madagascar and Burundi.

The predicted prevalence of porcine cysticercosisin circulating antigens and antibodies detection test in each country were higher than the predicted Prevalence of porcine cysticercosis using tongue examination and postmortem in the same country, but this difference was only statistically significant for Tanzania, Kenya, Uganda, South Africa, and Mozambique. There was observation of a significantly higher seroprevalence of porcine cysticercosis by antigen and antibody detection for studies that carried out both Tongue examination, postmortem, antigen and antibody detection tests. This distinct difference in the seroprevalence of circulating antigens or antibodies with Tongue examination or postmortem as observed by [59] [63] [72] [73] as shown in Table 3.

In this review, free range pig rearing, insufficient latrines or poor use of latrines [13] [33] [89], insufficiency sanitary [144], lack of health education to the community were reported as a significant risk factor both for the presence of circulating antigens and/or antibodies, Tongue examination and postmortem Table 3. Most studies revealed that the presence of pigs and the consumption of pork were also acknowledged as significant risk factors in favor of introduction of disease in the area [160].

At the time of writing this review there were no data about pigs reported for Djibouti, Comoros, Mauritania, Eritrea, Libya, Sudan, and Southern Sudan. This suggesting probably absence of pigs or insignificant pig rearing in the countries could be due to lack of professional for animal data collection in the country, or 
due to drought such as northern Africa region, also likely because most of the inhabitants in the region are Muslims. In the northern Africa countries there was no data available with regard to prevalence of porcine cysticercosis possibly because of non-availability of proper diagnostic facilities in the area or no pigs. Some countries had old data such as Togo, Egypt, Senegal, Gambia, Togo, and Guinea and Central African Republic.

Not all the studies offered details of the studied in sequence such as number of pigs in representativeness of each age group, health status of the pig such as presence of other pathogens that could have interfered when characterizing and comparing prevalence figures. Also were no studies selected for this review reported the presence of adult tapeworms in pigs' even postmortem studies concentrated only on muscle diagnosis but not intestinal diagnosis.

This review demonstrated the prevalence of porcine and human cysticercosis and exposure to the parasite in endemic countries in Africa, suggests that further studies have to be done in Africa to develop rapid tests serviceable at the farm level so that to detect infected animals in farms in order to offer safe meat for neighborhood demand. We recommend for additional studies because there is limited information on the prevalence of porcine cysticercosis in some countries in Africa because of non-availability of appropriate diagnostic facilities in various settings where these infections are widespread and no published articles on pig population and porcine cysticercosis from northern Africa. Most countries have old information such as Senegal, Gambia, Zimbabwe and Togo (e.g. [161] for Togo) therefore this study suggests that $T$. solium infection is more widespread than these data reported here because of insufficiency data as many countries with unknown data. The rapid epidemiological tool for evaluation of the prevalence of porcine cysticercosis is tongue examination for cyst, although further justification and refinement is necessary using standardized data sets.

High prevalence of porcine cysticercosis was observed in many articles in Africa with traditional pig rearing practices and villages with lack knowledge of the disease. In order to be successful, veterinary and medical public health services be supposed to find out foci of the disease transmission and work out on control strategies such as research, surveillance and control activities although will be needy on the presence of appropriate infrastructure. Therefore exposure was mostly related to environmental factors which varied from country to country.

The appropriate method to eliminate the problem is by using combination treatment by drugs or vaccine that expel parasitic worms (antworms) so that can eliminate existing infections in pigs and human, combined with increasing awareness as discussed about the risk factors.

\section{Acknowledgements}

We are thankful to the Jilin Agricultural University for the internet to download Data for this review. 


\section{Ethical Approval}

This article does not contain any studies with human participants or animals performed by any of the authors.

\section{Conflict of Interest}

Author 1 declares that she has no conflict of interest. Author 2 declares that he has no conflict of interest. Author 3 declares that she has no conflict of interest.

\section{References}

[1] García, H.H., Gonzalez, A.E., Evans, C.A.W. and Gilman, R.H. (2003) Cysticercosis Working Group in P: Taenia solium Cysticercosis. Lancet, 362, 547-556. https://doi.org/10.1016/S0140-6736(03)14117-7

[2] Kimbi, E., Mlangwa, J. and Thamsborg, S. (2015) Smallholder Pigs Production Systems in Tanzania. Journal of Agricultural Science and Technology, 5, 47-60.

[3] Madinga, J., Kanobana, K., Lukanu, P., Abatih, E., Baloji, S., Linsuke, S., Praet, N., Kapinga, S., Polman, K., Lutumba, P., et al. (2017) Geospatial and Age-Related Patterns of Taenia solium Taeniasis in the Rural Health Zone of Kimpese, Democratic Republic of Congo. Acta Tropica, 165, 100-109.

https://doi.org/10.1016/j.actatropica.2016.03.013

[4] Madzimure, J., Chimonyo, M., Zander, K.K. and Dzama, K. (2013) Potential for Using Indigenous Pigs in Subsistence-Oriented and Market-Oriented Small-Scale Farming Systems of Southern Africa. Tropical Animal Health and Production, 45, 135-142. https://doi.org/10.1007/s11250-012-0184-3

[5] Mekuriaw, Y. and Asmare, B. (2014) Assessment of Pig Production and Constraints in Mecha District, Amhara Region, Northwestern Ethiopia. Advances in Agriculture, 2014, Article ID: 329254. https://doi.org/10.1155/2014/329254

[6] Sibongiseni, T.G., James, W.O. and Mary, M.M. (2016) Pig Farming in Rural South Africa: A Case Study of Uthukela District in Kwa Zulu-Natal. Indian Journal of Animal Research, 50, 614-620.

[7] Eom, K.S., Chai, J.Y., Yong, T.S., Min, D.Y., Rim, H.J., Kihamia, C. and Jeon, H.K. (2011) Morphologic and Genetic Identification of Taenia tapeworms in Tanzania and DNA Genotyping of Taenia solium. The Korean Journal of Parasitology, 49, 399-403. https://doi.org/10.3347/kjp.2011.49.4.399

[8] Carabin, H., Winkler, A.S. and Dorny, P. (2017) Taenia solium Cysticercosis and Taeniosis: Achievements from the Past 10 Years and the Way Forward. PLOS Neglected Tropical Diseases, 11, e0005478. https://doi.org/10.1371/journal.pntd.0005478

[9] Ngowi, H.A., Kassuku, A.A., Carabin, H., Mlangwa, J.E.D., Mlozi, M.R.S., Mbiliny, B.P. and Willingham III, A.L. (2010) Spatial Clustering of Porcine Cysticercosis in Mbulu District, Northern Tanzania. PLOS Neglected Tropical Diseases, 4, e652. https://doi.org/10.1371/journal.pntd.0000652

[10] Omonisi, A.E., Aluko, J.A., Akinyemi, H.A., Alatishe, O.I. and Omoniyi-Esan, G.O. (2014) Human Cysticercosis of the Breast Mimicking Breast Cancer: A Report of a Case from Ile-Ife, Nigeria. Nigerian Journal of Medicine: Journal of the National Association of Resident Doctors of Nigeria, 4, 351-354.

[11] World Health Organization FaAOotUN, World Organisation for Animal Health, International Livestock Research Institute (2015) Assembling a Framework for In- 
tensified Control of Taeniasis and Neurocysticercosis Caused by Taenia solium, Report of an Informal Consultation. In: Abela Ridder, B., Ed., Neglected Zoonotic Diseases, WHO Headquarters, Geneva, vi, 32 p.

[12] Phiri, I.K., Ngowi, H., Afonso, S., Matenga, E., Boa, M., Mukaratirwa, S., Githigia, S., Saimo, M., Sikasunge, C., Maingi, N., et al. (2003) The Emergence of Taenia solium Cysticercosis in Eastern and Southern Africa as a Serious Agricultural Problem and Public Health Risk. Acta Tropica, 87, 13-23.

https://doi.org/10.1016/S0001-706X(03)00051-2

[13] Shonyela, S.M., Mkupasi, E.M., Sikalizyo, S.C., Kabemba, E.M., Ngowi, H.A. and Phiri, I. (2017) An Epidemiological Survey of Porcine Cysticercosis in Nyasa District, Ruvuma Region, Tanzania. Parasite Epidemiology and Control, 2, 35-41. https://doi.org/10.1016/j.parepi.2017.09.002

[14] Zoli, .A, Shey-Njila, O., Assana, E., Nguekam, J.P., Dorny, P., Brandt, J. and Geerts, S. (2003) Regional Status, Epidemiology and Impact of Taenia solium Cysticercosis in Western and Central Africa. Acta Tropica, 87, 35-42. https://doi.org/10.1016/S0001-706X(03)00053-6

[15] Assane, Y.A., Trevisan, C., Schutte, C.M., Noormahomed, E.V., Johansen, M.V. and Magnussen, P. (2017) Neurocysticercosis in a Rural Population with Extensive Pig Production in Angonia District, Tete Province, Mozambique. Acta Tropica, 165, 155-160. https://doi.org/10.1016/j.actatropica.2015.10.018

[16] Yanagida, T., Carod, J.-F., Sako, Y., Nakao, M., Hoberg, E.P. and Ito, A. (2014) Genetics of the Pig Tapeworm in Madagascar Reveal a History of Human Dispersal and Colonization. PLOS ONE, 9, e109002. https://doi.org/10.1371/journal.pone.0109002

[17] Murrell, K.D., Flisser, A., Geerts, S., Kyvsgaard, N.C. and Mcmanus, D.P. (2005) WHO/FAO/OIE: Guidelines for the Surveillance, Prevention and Control of Taeniosis/Cysticercosis. OIE (World Organisation for Animal Health), World Health Organization and the Food and Agriculture Organization of the United Nations (FAO), $139 \mathrm{p}$.

[18] Tomlinson, M., Adams, V., Chopra, M., Jooste, P., Strydom, E. and Dhansay, A. (2010) Survey of Iodine Deficiency and Intestinal Parasitic Infections in School-Going Children: Bie Province, Angola. Public Health Nutrition, 13, 1314-1318. https://doi.org/10.1017/S1368980010000510

[19] Carabin, H., Millogo, A., Praet, N., Hounton, S., Tarnagda, Z., Ganaba, R., Dorny, P., Nitiéma, P., Cowan, L.D. and Évaluation du Fardeau Économique de la Cysticercose Au Burkina Faso (ÉFÉCAB) (2009) Seroprevalence to the Antigens of Taenia solium Cysticercosis among Residents of Three Villages in Burkina Faso: A Cross-Sectional Study. PLOS Neglected Tropical Diseases, 3, e555. https://doi.org/10.1371/journal.pntd.0000555

[20] Buttery, J. (2015) Pig Population by Country. Anivax, Inc in LinkedIn.

[21] Braae, U.C., Saarnak, C.F.L., Mukaratirwa, S., Devleesschauwer, B., Magnussen, P. and Johansen, M.V. (2015) Taenia solium Taeniosis/Cysticercosis and the Co-Distribution with Schistosomiasis in Africa. Parasites \& Vectors, 8, 323. https://doi.org/10.1186/s13071-015-0938-7

[22] Praet, N., Kanobana, K., Kabwe, C., Maketa, V., Lukanu, P., Lutumba, P., Polman, K., Matondo, P., Speybroeck, N., Dorny, P., et al. (2010) Taenia solium Cysticercosis in the Democratic Republic of Congo: How Does Pork Trade Affect the Transmission of the Parasite? PLOS Neglected Tropical Diseases, 4, e817.

https://doi.org/10.1371/journal.pntd.0000817 
[23] Dorny, P., Kabwe, C., Kirezi, K., Lukanu, K., Lutumba, P., Maketa, V., Matondo, P., Polman, K., Praet, N., Speybroeck, N., et al. (2012) Cysticercosis in the Democratic Republic of Congo. Onderstepoort Journal of Veterinary Research, 79, a485. https://doi.org/10.4102/ojvr.v79i2.485

[24] Ndimubanzi, P.C., Carabin, H., Budke, C.M., Nguyen, H., Qian, Y.-J., Rainwater, E., Dickey, M., Reynolds, S. and Stoner, J.A. (2010) A Systematic Review of the Frequency of Neurocyticercosis with a Focus on People with Epilepsy. PLOS Neglected Tropical Diseases, 4, e870. https://doi.org/10.1371/journal.pntd.0000870

[25] Zirintunda, G. and Ekou, J. (2015) Occurrence of Porcine Cysticercosis in Free-Ranging Pigs Delivered to Slaughter Points in Arapai, Soroti District, Uganda. Onderstepoort Journal of Veterinary Research, 82, 888.

https://doi.org/10.4102/ojvr.v82i1.888

[26] Boa, M.E., Mahundi, E.A., Kassuku, A.A., Willingham, A.L. and Kyvsgaard, N.C. (2006) Epidemiological Survey of Swine Cysticercosis Using Ante-Mortem and Post-Mortem Examination Tests in the Southern Highlands of Tanzania. Veterinary Parasitology, 139, 249-255. https://doi.org/10.1016/j.vetpar.2006.02.012

[27] Thomas, L.F., de Glanville, W.A., Cook, E.A.J., Bronsvoort, B.M.D.C., Handel, I., Wamae, C.N., Kariuki, S. and Fèvre, E.M. (2017) Modelling the Risk of Taenia solium Exposure from Pork Produced in Western Kenya. PLOS Neglected Tropical Diseases, 11, e0005371. https://doi.org/10.1371/journal.pntd.0005371

[28] Ngowi, H.A., Kassuku, A.A., Maeda, G.E., Boa, M.E., Carabin, H. and Willingham, A.L. (2004) Risk Factors for the Prevalence of Porcine Cysticercosis in Mbulu District, Tanzania. Veterinary Parasitology, 120, 275-283.

[29] Karimuribo, E.D., Makene, V.W. and Mathias, S. (2011) Characteristics and Production Constraints of Rural-Based Small-Scale Pig Farming in Iringa Region, Tanzania. Livestock Research for Rural Development, 23, 8.

[30] Krecek, R.C., Mohammed, H., Michael, L.M., Schantz, P.M., Ntanjana, L., Morey, L., Were, S.R. and Willingham III, A.L. (2012) Risk Factors of Porcine Cysticercosis in the Eastern Cape Province, South Africa. PLoS ONE, 7, e37718. https://doi.org/10.1371/journal.pone.0037718

[31] Eshitera, E.E., Githigia, S.M., Kitala, P., Thomas, L.F., Fevre, E.M., Harrison, L.J., Mwihia, E.W., Otieno, R.O., Ojiambo, F. and Maingi, N. (2012) Prevalence of Porcine Cysticercosis and Associated Risk Factors in Homa Bay District, Kenya. BMC Veterinary Research, 8, 234. https://doi.org/10.1186/1746-6148-8-234

[32] Kungu, J.M., Dione, M.M., Ejobi, F., Ocaido, M. and Grace, D. (2017) Risk Factors, Perceptions and Practices Associated with Taenia solium Cysticercosis and Its Control in the Smallholder Pig Production Systems in Uganda: A Cross-Sectional Survey. BMC Infectious Diseases, 17, 1. https://doi.org/10.1186/s12879-016-2122-x

[33] Sikasunge, C.S., Phiri, I.K., Phiri, A.M., Dorny, P., Siziya, S. and Willingham, A.L. (2007) Risk Factors Associated with Porcine Cysticercosis in Selected Districts of Eastern and Southern Provinces of Zambia. Veterinary Parasitology, 143, 59-66. https://doi.org/10.1016/j.vetpar.2006.07.023

[34] Pondja, A., Neves, L., Mlangwa, J., Afonso, S., Fafetine, J., Willingham, A.L., Thamsborg, S.M. and Johansen, M.V. (2010) Prevalence and Risk Factors of Porcine Cysticercosis in Angónia District, Mozambique. PLOS Neglected Tropical Diseases, 4, e594. https://doi.org/10.1371/journal.pntd.0000594

[35] Secka, A., Marcotty, T., De Deken, R., Van Marck, E. and Geerts, S. (2010) Porcine Cysticercosis and Risk Factors in the Gambia and Senegal. Journal of Parasitology Research, 2010, Article ID: 823892. 
[36] Salvetti, E. and O'Toole, P.W. (2017) When Regulation Challenges Innovation: The Case of the Genus Lactobacillus. Trends in Food Science \& Technology, 66, 187-194. https://doi.org/10.1016/j.tifs.2017.05.009

[37] Prasad, K.N., Chawla, S., Prasad, A., Tripathi, M., Husain, N. and Gupta, R.K. (2006) Clinical Signs for Identification of Neurocysticercosis in Swine Naturally Infected with Taenia solium. Parasitology International, 55, 151-154. https://doi.org/10.1016/j.parint.2006.01.002

[38] Guyatt, H.L. and Fèvre, E.M. (2016) Lingual Palpation for Porcine Cysticercosis: A Rapid Epidemiological Tool for Estimating Prevalence and Community Risk in Africa. Tropical Medicine \& International Health, 21, 1319-1323. https://doi.org/10.1111/tmi.12760

[39] Silva, M.R.Md., Uyhara, C.N.S., Silva, F.H., Espindola, N.M., Poleti, M.D., Vaz, A.J., Meirelles, F.V. and Maia, A.A.M. (2012) Cysticercosis in Experimentally and Naturally Infected Pigs: Parasitological and Immunological Diagnosis. Pesquisa Veterinária Brasileira, 32, 297-302. https://doi.org/10.1590/S0100-736X2012000400005

[40] Thomas, L.F., Harrison, L.J.S., Toye, P., de Glanville, W.A., Cook, E.A.J., Wamae, C.N. and Fèvre, E.M. (2016) Prevalence of Taenia solium Cysticercosis in Pigs Entering the Food Chain in Western Kenya. Tropical Animal Health and Production, 48, 233-238. https://doi.org/10.1007/s11250-015-0949-6

[41] Mkupasi, E.M., Ngowi, H.A. and Nonga, H.E. (2011) Prevalence of Extra-Intestinal Porcine Helminth Infections and Assessment of Sanitary Conditions of Pig Slaughter Slabs in Dar es Salaam City, Tanzania. Tropical Animal Health and Production, 43, 417-423. https://doi.org/10.1007/s11250-010-9708-x

[42] Mellau, B.L., Nonga, H.E. and Karimuribo, E.D. (2011) Slaughter Stock Abattoir Survey of Carcasses and Organ/Offal Condemnations in Arusha Region, Northern Tanzania. Tropical Animal Health and Production, 43, 857-864.

[43] Tran, A., Talmud, D., Lejeune, B., Jovenin, N., Renois, F., Payan, C., Leveque, N. and Andreoletti, L. (2010) Prevalence of Rotavirus, Adenovirus, Norovirus, and Astrovirus Infections and Coinfections among Hospitalized Children in Northern France. Journal of Clinical Microbiology, 48, 1943-1946. https://doi.org/10.1128/JCM.02181-09

[44] Collins, P.L. and Graham, B.S. (2008) Viral and Host Factors in Human Respiratory Syncytial Virus Pathogenesis. Journal of Virology, 82, 2040-2055. https://doi.org/10.1128/JVI.01625-07

[45] Sikasunge, C.S., Phiri, I.K., Phiri, A.M., Siziya, S., Dorny, P. and Willingham, A.L. (2008) Prevalence of Taenia solium Porcine Cysticercosis in the Eastern, Southern and Western Provinces of Zambia. The Veterinary Journal, 176, 240-244.

[46] Karshima, N.S., Udokainyang, A.D. and Salihu, A.A. (2013) Taenia solium Cysticercosis in Pigs Slaughtered in IBI Local Government Area of Taraba State, Nigeria.

[47] Mwanjali, G., Kihamia, C., Kakoko, D.V., Lekule, F., Ngowi, H., Johansen, M.V., Thamsborg, S.M. and Willingham 3rd, A.L. (2013) Prevalence and Risk Factors Associated with Human Taenia solium Infections in Mbozi District, Mbeya Region, Tanzania. PLOS Neglected Tropical Diseases, 7, e2102. https://doi.org/10.1371/journal.pntd.0002102

[48] Pondja, A., Neves, L., Mlangwa, J., Afonso, S., Fafetine, J., Willingham, A.L., Thamsborg, S.M. and Johansen, M.V. (2015) Incidence of Porcine Cysticercosis in Angónia District, Mozambique. Preventive Veterinary Medicine, 118, 493-497. https://doi.org/10.1016/j.prevetmed.2015.01.001

[49] Mwape, K.E., Phiri, I.K., Praet, N., Speybroeck, N., Muma, J.B. and Dorny, P. (2013) 
The Incidence of Human Cysticercosis in a Rural Community of Eastern Zambia. PLOS Neglected Tropical Diseases, 7, e2142. https://doi.org/10.1371/journal.pntd.0002142

[50] Praet, N., Verweij, J.J., Mwape, K.E., Phiri, I.K., Muma, J.B., Zulu, G., van Lieshout, L., Rodriguez-Hidalgo, R., Benitez-Ortiz, W., Dorny, P., et al. (2013) Bayesian Modelling to Estimate the Test Characteristics of Coprology, Coproantigen ELISA and a Novel Real-Time PCR for the Diagnosis of Taeniasis. Tropical Medicine \& International Health: TM \& IH, 18, 608-614. https://doi.org/10.1111/tmi.12089

[51] Braae, U.C., Magnussen, P., Lekule, F., Harrison, W. and Johansen, M.V. (2014) Temporal Fluctuations in the Sero-Prevalence of Taenia solium Cysticercosis in Pigs in Mbeya Region, Tanzania. Parasites \& Vectors, 7, 574.

https://doi.org/10.1186/s13071-014-0574-7

[52] Ramahefarisoa, R.M., Rakotondrazaka, M., Jambou, R. and Carod, J.F. (2010) Comparison of ELISA and PCR Assays for the Diagnosis of Porcine Cysticercosis. Veterinary Parasitology, 173, 336-339. https://doi.org/10.1016/j.vetpar.2010.05.002

[53] Winkler, A.S., Blocher, J., Auer, H., Gotwald, T., Matuja, W. and Schmutzhard, E. (2008) Anticysticercal and Antitoxocaral Antibodies in People with Epilepsy in Rural Tanzania. Transactions of the Royal Society of Tropical Medicine and Hygiene, 102, 1032-1038. https://doi.org/10.1016/j.trstmh.2008.05.004

[54] Winkler, A.S., Blocher, J., Auer, H., Gotwald, T., Matuja, W. and Schmutzhard, E. (2009) Epilepsy and Neurocysticercosis in Rural Tanzania-An Imaging Study. Epilepsia, 50, 987-993. https://doi.org/10.1111/j.1528-1167.2008.01867.x

[55] Donadeu, M., Fahrion, A.S., Olliaro, P.L. and Abela-Ridder, B. (2017) Target Product Profiles for the Diagnosis of Taenia solium Taeniasis, Neurocysticercosis and Porcine Cysticercosis. PLOS Neglected Tropical Diseases, 11, e0005875. https://doi.org/10.1371/journal.pntd.0005875

[56] Bustos, J.A., Rodriguez, S., Jimenez, J.A., Moyano, L.M., Castillo, Y., Ayvar, V., Allan, J.C., Craig, P.S., Gonzalez, A.E., Gilman, R.H., et al. (2012) Detection of Taenia solium Taeniasis Coproantigen Is an Early Indicator of Treatment Failure for Taeniasis. Clinical and Vaccine Immunology, 19, 570-573. https://doi.org/10.1128/CVI.05428-11

[57] Nkouawa, A., Dschanou, A.R., Moyou-Somo, R., Sako, Y. and Ito, A. (2017) Seroprevalence and Risk Factors of Human Cysticercosis and Taeniasis Prevalence in a Highly Endemic Area of Epilepsy in Bangoua, West Cameroon. Acta Tropica, 165, 116-120. https://doi.org/10.1016/j.actatropica.2015.12.019

[58] Michelet, L., Carod, J.F., Rakontondrazaka, M., Ma, L., Gay, F. and Dauga, C. (2010) The Pig Tapeworm Taenia solium, the Cause of Cysticercosis: Biogeographic (Temporal and Spacial) Origins in Madagascar. Molecular Phylogenetics and Evolution, 55, 744-750. https://doi.org/10.1016/j.ympev.2010.01.008

[59] Assana, E., Amadou, F., Thys, E., Lightowlers, M.W., Zoli, A.P. and Dorny, P. (2010) Pig-Farming Systems and Porcine Cysticercosis in the North of Cameroon. Journal of Helminthology, 84, 441-446.

[60] Porphyre, V., Betson, M., Rabezanahary, H., Mboussou, Y., Zafindraibe, N.J., Rasamoelina-Andriamanivo, H., Costard, S., Pfeiffer, D.U. and Michault, A. (2016) Taenia solium Porcine Cysticercosis in Madagascar: Comparison of Immuno-Diagnostic Techniques and Estimation of the Prevalence in Pork Carcasses Traded in Antananarivo City. Veterinary Parasitology, 219, 77-83. https://doi.org/10.1016/j.vetpar.2015.08.027

[61] Krecek, R.C., Michael, L.M., Schantz, P.M., Ntanjana, L., Smith, M.F., Dorny, P., 
Harrison, L.J., Grimm, F., Praet, N. and Willingham 3rd, A.L. (2008) Prevalence of Taenia solium Cysticercosis in Swine from a Community-Based Study in 21 Villages of the Eastern Cape Province, South Africa. Veterinary Parasitology, 154, 38-47.

[62] Nkouawa, A., Sako, Y., Itoh, S., Kouojip-Mabou, A., Nganou, C.N., Saijo, Y., Knapp, J., Yamasaki, H., Nakao, M., Nakaya, K., et al. (2010) Serological Studies of Neurologic Helminthic Infections in Rural Areas of Southwest Cameroon: Toxocariasis, Cysticercosis and Paragonimiasis. PLOS Neglected Tropical Diseases, 4, e732. https://doi.org/10.1371/journal.pntd.0000732

[63] Pouedet, M.S.R., Zoli, A.P., Vondou, L., Assana, E., Speybroeck, N., Berkvens, D., Dorny, P., Brandt, J. and Geerts, S. (2002) Epidemiological Survey of Swine Cysticercosis in Two Rural Communities of West-Cameroon. Veterinary Parasitology, 106, 45-54.

[64] Braae, U.C., Magnussen, P., Harrison, W., Ndawi, B., Lekule, F. and Johansen, M.V. (2016) Effect of National Schistosomiasis Control Programme on Taenia solium Taeniosis and Porcine Cysticercosis in Rural Communities of Tanzania. Parasite Epidemiology and Control, 1, 245-251.

[65] Mwape, K.E., Phiri, I.K., Praet, N., Muma, J.B., Zulu, G. and Bossche, P. (2012) Taenia solium Infections in a Rural Area of Eastern Zambia-A Community Based Study. PLOS Neglected Tropical Diseases, 6, e1594.

[66] Rottbeck, R., Nshimiyimana, J.F., Tugirimana, P., Düll, U.E., Sattler, J. and Hategekimana, J.-C. (2013) High Prevalence of Cysticercosis in People with Epilepsy in Southern Rwanda. PLOS Neglected Tropical Diseases, 7, e2558. https://doi.org/10.1371/journal.pntd.0002558

[67] Guezala, M.C., Rodriguez, S., Zamora, H., Garcia, H.H., Gonzalez, A.E., Tembo, A., Allan, J.C. and Craig, P.S. (2009) Development of a Species-Specific Coproantigen ELISA for Human Taenia solium Taeniasis. The American Journal of Tropical Medicine and Hygiene, 81, 433-437.

[68] Nunes, C.M., Lima, L.G., Manoel, C.S., Pereira, R.N., Nakano, M.M. and Garcia, J.F. (2003) Taenia saginata: Polymerase Chain Reaction for Taeniasis Diagnosis in $\mathrm{Hu}-$ man Fecal Samples. Experimental Parasitology, 104, 67-69. https://doi.org/10.1016/S0014-4894(03)00111-5

[69] Blocher, J., Schmutzhard, E., Wilkins, P.P., Gupton, P.N., Schaffert, M., Auer, H., Gotwald, T., Matuja, W. and Winkler, A.S. (2011) A Cross-Sectional Study of People with Epilepsy and Neurocysticercosis in Tanzania: Clinical Characteristics and Diagnostic Approaches. PLOS Neglected Tropical Diseases, 5, e1185. https://doi.org/10.1371/journal.pntd.0001185

[70] Johansen, M.V., Trevisan, C., Gabriel, S., Magnussen, P. and Braae, U.C. (2017) Are We Ready for Taenia solium Cysticercosis Elimination in Sub-Saharan Africa? Parasitology, 144, 59-64. https://doi.org/10.1017/S0031182016000500

[71] Komba, E.V., Kimbi, E.C., Ngowi, H.A., Kimera, S.I., Mlangwa, J.E., Lekule, F.P., Sikasunge, C.S., Willingham 3rd, A.L., Johansen, M.V. and Thamsborg, S.M. (2013) Prevalence of Porcine Cysticercosis and Associated Risk Factors in Smallholder Pig Production Systems in Mbeya Region, Southern Highlands of Tanzania. Veterinary Parasitology, 198, 284-291. https://doi.org/10.1016/j.vetpar.2013.09.020

[72] Porphyre, V., Rasamoelina-Andriamanivo, H., Rakotoarimanana, A., Rasamoelina, O., Bernard, C., Jambou, R. and Cardinale, E. (2015) Spatio-Temporal Prevalence of Porcine Cysticercosis in Madagascar Based on Meat Inspection. Parasites \& Vectors, 8, 391. https://doi.org/10.1186/s13071-015-0975-2

[73] Krecek, R.C., Michael, L.M., Schantz, P.M., Ntanjana, L., Smith, M.F., Dorny, P., 
Harrison, L.J., Grimm, F., Praet, N. and Willingham 3rd, A.L. (2008) Prevalence of Taenia solium Cysticercosis in Swine from a Community-Based Study in 21 Villages of the Eastern Cape Province, South Africa. Veterinary Parasitology, 154, 38-47. https://doi.org/10.1016/j.vetpar.2008.03.005

[74] Trevisan, C., Devleesschauwer, B., Schmidt, V., Winkler, A.S., Harrison, W. and Johansen, M.V. (2017) The Societal Cost of Taenia solium Cysticercosis in Tanzania. Acta Tropicaica, 165, 141-154. https://doi.org/10.1016/j.actatropica.2015.12.021

[75] Kavishe, M.D.B., Komba, E.V.G. and Ngowi, H.A. (2017) Prevalence and Risk Factors Associated with Porcine Cysticercosis Transmission in Babati District, Tanzania. Livestock Research for Rural Development, 29, Article \#16. http://www.lrrd.org/lrrd29/1/kavi29016.html

[76] Ertel, R.L., Braae, U.C., Ngowi, H.A. and Johansen, M.V. (2017) Assessment of a Computer-Based Taenia solium Health Education Tool "The Vicious Worm" on Knowledge Uptake among Professionals and Their Attitudes towards the Program. Acta Tropica, 165, 240-245. https://doi.org/10.1016/j.actatropica.2015.10.022

[77] Schur, N., Hurlimann, E., Garba, A., Traore, M.S., Ndir, O., Ratard, R.C., Tchuem Tchuente, L.A., Kristensen, T.K., Utzinger, J. and Vounatsou, P. (2011) Geostatistical Model-Based Estimates of Schistosomiasis Prevalence among Individuals Aged $</=20$ Years in West Africa. PLOS Neglected Tropical Diseases, 5, e1194. https://doi.org/10.1371/journal.pntd.0001194

[78] Cortnum, S., Knudsen, K.B. and Sorensen, P. (2011) Surgical Treatment of Neurocysticercosis in a 12-Year Old Child. Ugeskrift for Laeger, 173, 2203-2204.

[79] Buttery, J. (2015) Pig Population by Country. Anivax, Inc in LinkedIn.

[80] Nitiema, P., Carabin, H., Hounton, S., Praet, N., Cowan, L.D., Ganaba, R., Kompaore, C., Tarnagda, Z., Dorny, P., Millogo, A., et al. (2012) Prevalence Case-Control Study of Epilepsy in Three Burkina Faso Villages. Acta Neurologica Scandinavica, 126, 270-278. https://doi.org/10.1111/j.1600-0404.2011.01639.x

[81] Lightowlers, M.W., Assana, E., Jayashi, C.M., Gauci, C.G. and Donadeu, M. (2015) Sensitivity of Partial Carcass Dissection for Assessment of Porcine Cysticercosis at Necropsy. International Journal for Parasitology, 45, 815-818. https://doi.org/10.1016/j.ijpara.2015.08.004

[82] Kambashi, B., Boudry, C., Théwis, A. and Kiatoko, H. (2014) Smallholder Pig Production Systems along a Periurban-Rural Gradient in the Western Provinces of the Democratic Republic of the Congo. Journal of Agriculture and Rural Development in the Tropics and Subtropics, 115, 9-22.

[83] Elmonir, W., Mousa, W. and Sultan, K. (2015) The Prevalence of Some Parasitic Zoonoses in Different Slaughtered Animal Species at Abattoir in the Mid-Delta of Egypt; with Special Reference to Its Economic Implications. Alexandria Journal of Veterinary Sciences, 47, 97-103. https://doi.org/10.5455/ajvs.204290

[84] Abdel-Hafeez, E.H., Kamal, A.M., Abdelgelil, N.H. and Abdel-Fatah, M. (2015) Parasites Transmitted to Human by Ingestion of Different Types of Meat, El-Minia City, El-Minia Governorate, Egypt. Journal of the Egyptian Society of Parasitology, 45, 671-680. https://doi.org/10.12816/0017935

[85] Secka, A., Marcotty, T., De Deken, R., Van Marck, E. and Geerts, S. (2010) Porcine Cysticercosis and Risk Factors in the Gambia and Senegal. Journal of Parasitology Research, 2010, Article ID: 823892. https://doi.org/10.1155/2010/823892

[86] Bimi, L., Laar, A.K. and Anto, F. (2012) Prevalence and Risk Factors of Taeniasis in the Bunkpurugu-Yunyoo District of Northern Ghana. Journal of Bacteriology \& 
Parasitology, 3, 129. https://doi.org/10.4172/2155-9597.1000129

[87] Atawalna, J. and Mensah, S. (2015) Prevalence and Financial Losses Associated with Porcine Cysticercosis in the Kumasi Metropolis of Ghana. International Journal of Livestock Research, 5, 21-26. https://doi.org/10.5455/ijlr.20150825044155

[88] Wardrop, N.A., Thomas, L.F., Atkinson, P.M., de Glanville, W.A., Cook, E.A.J., Wamae, C.N., Gabriël, S., Dorny, P., Harrison, L.J.S. and Fèvre, E.M. (2015) The Influence of Socio-Economic, Behavioural and Environmental Factors on Taenia spp. Transmission in Western Kenya: Evidence from a Cross-Sectional Survey in $\mathrm{Hu}$ mans and Pigs. PLOS Neglected Tropical Diseases, 9, e0004223. https://doi.org/10.1371/journal.pntd.0004223

[89] Nantima, M.O., Davies, J., Dione, M., Okoth, E., Mugisha, A. and Bishop, R. (2015) Characterization of Smallholder Pig Production Systems in Four Districts along the Uganda-Kenya Border.

[90] Mutua, F.K.R., Arimi, T.F., Kitala, S.M., et al. (2007) Palpable Lingual Cysts, a Possible Indicator of Porcine Cysticercosis, in Teso District, Western Kenya. Journal of Swine Health and Production, 15, 206-212.

[91] Githigia, A.M. and Otieno, R.O. (2005) Prevalence of Porcine Cysticercosis and Risk Factors for Taenia solium Taeniosis in Funyula Division of Busia District, Kenya. The Kenya Veterinarian, 29, 37-39.

[92] Rasamoelina-Andriamanivo, H., Porphyre, V. and Jambou, R. (2013) Control of Cysticercosis in Madagascar: Beware of the Pitfalls. Trends in Parasitology, 29, 538-547. https://doi.org/10.1016/j.pt.2013.09.002

[93] Schmidt, V., Sikasunge, C.S., Odongo-Aginya, E., Simukoko, C., Mwanjali, G., Alarakol, S., Ovuga, E., Matuja, W., Kihamia, C., Löscher, T., et al. (2015) Taenia solium Metacestode Preparation in Rural Areas of Sub-Saharan Africa: A Source for Diagnosis and Research on Cysticercosis. African Health Sciences, 15, 58-67. https://doi.org/10.4314/ahs.v15i1.8

[94] Afonso, S.M., Vaz, Y., Neves, L., Pondja, A., Dias, G., Willingham, A.L., Vilhena, M., Duarte, P.C., Jost, C.C. and Noormahomed, E.V. (2011) Human and Porcine Taenia solium Infections in Mozambique: Identifying Research Priorities. Animal Health Research Reviews, 12, 123-129. https://doi.org/10.1017/S1466252311000077

[95] Pondja, A., Neves, L., Mlangwa, J., Afonso, S., Fafetine, J., Willingham, A.L. III, Thamsborg, S.M. and Johansen, M.V. (2012) Use of Oxfendazole to Control Porcine Cysticercosis in a High-Endemic Area of Mozambique. PLOS Neglected Tropical Diseases, 6, e1651. https://doi.org/10.1371/journal.pntd.0001651

[96] Edia-Asuke, A.U., Inabo, H.I., Umoh, V.J., Whong, C.M., Asuke, S. and Edeh, R.E. (2014) Assessment of Sanitary Conditions of Unregistered Pig Slaughter Slabs and Post Mortem Examination of Pigs for Taenia solium Metacestodes in Kaduna Metropolis, Nigeria. Infectious Diseases of Poverty, 3, 45. https://doi.org/10.1186/2049-9957-3-45

[97] AA B (2012) Prevalence and Morphometric Studies on Porcine Cysticercosis in Adamawa State, Nigeria.

[98] Gweba, M., Faleke, O.O., Junaidu, A., Fabiyi, J.P. and Fajinmi, A.O. (2010) Some Risk Factors for Taenia solium Cysticercosis in Semi-Intensively Raised Pigs in Zuru, Nigeria. Veterinaria Italiana, 46, 57-67.

[99] Rebecca, W.P., Eugene, I.I. and Joshua, K. (2013) Seroprevalence of Antibodies (IgG) to Taenia solium among Pig Rearers and Associated Risk Factors in Jos Metropolis, Nigeria. Journal of Infection in Developing Countries, 7, 67-72. https://doi.org/10.3855/jidc.2309 
[100] Weka, R.P. and Ikeh, E.I. (2008) Seroprevalence of Cysticercosis and Intestinal Parasitism in Pigs in Jos Metropolis. Journal of Animal and Veterinary Advances, 8 , 883-887.

[101] Krecek, R.C., Michael, L.M., Schantz, P.M., Ntanjana, L., Smith, M.F., Dorny, P., Harrison, L.J.S., Grimm, F., Praet, N. and Willingham, A.L. (2011) Corrigendum to Prevalence of Taenia solium Cysticercosis in Swine from a Community-Based Study in 21 Villages of the Eastern Cape Province, South Africa. Veterinary Parasitology, 154, 38-47. https://doi.org/10.1016/j.vetpar.2008.03.005

[102] Boa, M., Mukaratirwa, S., Willingham, A.L. and Johansen, M.V. (2003) Regional Action Plan for Combating Taenia solium Cysticercosis/Taeniosis in Eastern and Southern Africa. Acta Tropicaica, 87, 183-186.

[103] Lipendele, C.P., Lekule, F.P., Mushi, D.E., Ngowi, H., Kimbi, E.C., Mejer, H., Thamsborg, S.M. and Johansen, M.V. (2015) Productivity and Parasitic Infections of Pigs Kept under Different Management Systems by Smallholder Farmers in Mbeya and Mbozi Districts, Tanzania. Tropical Animal Health and Production, 47, 1121-1130. https://doi.org/10.1007/s11250-015-0836-1

[104] Mwang'onde, B.J., Nkwengulila, G. and Chacha, M. (2014) The Risk Factors for Human Cysticercosis in Mbulu District, Tanzania. Journal of Veterinary Research, 81, a719. https://doi.org/10.4102/ojvr.v81i2.719

[105] Ngowi, H.A., Mkupasi, E.M., Lekule, F.P., Willingham, A.L. and Thamsborg, S.M. (2011) Impact of Farmer Education on Their Knowledge, Attitudes, and Practices in Southern Tanzania: A Case for Taenia solium Control. Livestock Research for Rural Development, 23, Article \#2. http://www.lrrd.org/lrrd23/1/ngow23002.htm

[106] Yohana, C., Mwita, C.J. and Nkwengulila, G. (2013) The Prevalence of Porcine Cysticercosis and Risk Factors for Taeniasis in Iringa Rural District. International Journal of Animal and Veterinary Advances, 5, 251-255.

[107] Goussanou, J.S.E., Kpodekon, M.T., Youssao, A.K.I., Farougou, S. and Korsak, N. (2014) Epidemiological Tools for Effective Surveillance of Porcine Cysticercosis in Africa. Veterinary World, 7, 125-134. https://doi.org/10.14202/vetworld.2014.125-134

[108] Ngowi, H.A., Carabin, H., Kassuku, A.A., Mlozi, M.R., Mlangwa, J.E. and Willingham 3rd, A.L. (2008) A Health-Education Intervention Trial to Reduce Porcine Cysticercosis in Mbulu District, Tanzania. Preventive Veterinary Medicine, 85, 52-67. https://doi.org/10.1016/j.prevetmed.2007.12.014

[109] Kungu, J.M., Dione, M.M., Ejobi, F., Harrison, L.J.S., Poole, E.J., Pezo, D. and Grace, D. (2017) Sero-Prevalence of Taenia spp. Cysticercosis in Rural and Urban Smallholder Pig Production Settings in Uganda. Acta Tropicaica, 165, 110-115. https://doi.org/10.1016/j.actatropica.2016.01.016

[110] Nsadha, Z., Thomas, L.F., Févre, E.M., Nasinyama, G., Ojok, L. and Waiswa, C. (2014) Prevalence of Porcine Cysticercosis in the Lake Kyoga Basin, Uganda. BMC Veterinary Research, 10, 239. https://doi.org/10.1186/s12917-014-0239-y

[111] Nsadha, Z., Saimo, M., Waiswa, C., Maingi, N., Ojok, L., Willingham, A.L., Mutagwanya, R., Nyakarhuka, L. and Lubega, G. (2010) Risk Factors and Lingual Prevalence of Porcine Cysticercosis in the Lake Kyoga Basin in Uganda. Africa Journal of Animal and Biomedical Sciences, 5, 43-50.

[112] Waiswa, C., Fèvre, E.M., Nsadha, Z., Sikasunge, C.S. and Willingham Iii, A.L. (2009) Porcine Cysticercosis in Southeast Uganda: Seroprevalence in Kamuli and Kaliro Districts. Journal of Parasitology Research, 2009, Article ID: 375493. https://doi.org/10.1155/2009/375493 
[113] Waiswa, C., Olaho-Mukani, W. and Katunguka-Rwakishaya, E. (2003) Packed Cell Volume as a Measure of Procine Health and the Implication on the Control of Sleeping Sickness in Uganda. Bulgarian Journal of Veterinary Medicine, 6, 187-191.

[114] Thys, S., Mwape, K.E., Lefèvre, P., Dorny, P., Phiri, A.M., Marcotty, T., Phiri, I.K. and Gabriël, S. (2016) Why Pigs Are Free-Roaming: Communities' Perceptions, Knowledge and Practices Regarding Pig Management and Taeniosis/Cysticercosis in a Taenia solium Endemic Rural Area in Eastern Zambiatle. Veterinary Parasitology, 225, 33-42. https://doi.org/10.1016/j.vetpar.2016.05.029

[115] Sikasunge, C., Siziya, S., Vercruysse, J., Phiri, I.K., Dorny, P., Gabriel, S. and Willingham, A.L. (2006) Assessment of Routine Inspection Methods for Porcine Cysticercosis in Zambian Village Pigs. Journal of Helminthology, 80, 69-72. https://doi.org/10.1079/JOH2005314

[116] Sikasunge, C.S., Johansen, M.V., Willingham, A.L., Leifsson, P.S. and Phiri, I.K. (2008) Taenia solium Porcine Cysticercosis: Viability of Cysticerci and Persistency of Antibodies and Cysticercal Antigens after Treatment with Oxfendazole. Veterinary Parasitology, 158, 57-66. https://doi.org/10.1016/j.vetpar.2008.08.014

[117] Phiri, I.K., Dorny, P., Gabriel, S., Willingham, A.L., Speybroeck, N. and Vercruysse, J. (2002) The Prevalence of Porcine Cysticercosis in Eastern and Southern Provinces of Zambia. Veterinary Parasitology, 108, 31-39. https://doi.org/10.1016/S0304-4017(02)00165-6

[118] Mwape, K.E., Blocher, J., Wiefek, J., Schmidt, K., Dorny, P. and Praet, N. (2015) Prevalence of Neurocysticercosis in People with Epilepsy in the Eastern Province of Zambia. PLOS Neglected Tropical Diseases, 9, e0003972. https://doi.org/10.1371/journal.pntd.0003972

[119] Phiri, I.K., Dorny, P., Gabriel, S., Willingham, A.L. 3rd, Sikasunge, C., Siziya, S. and Vercruysse, J. (2006) Assessment of Routine Inspection Methods for Porcine Cysticercosis in Zambian Village Pigs. Journal of Helminthology, 80, 69-72. https://doi.org/10.1079/JOH2005314

[120] Gabriel, S., Dorny, P., Mwape, K.E., Trevisan, C., Braae, U.C., Magnussen, P., Thys, S., Bulaya, C., Phiri, I.K., Sikasunge, C.S., et al. (2017) Control of Taenia solium Taeniasis/Cysticercosis: The Best Way forward for Sub-Saharan Africa? Acta Tropicaica, 165, 252-260. https://doi.org/10.1016/j.actatropica.2016.04.010

[121] Matenga, E.M.S. and Willingham, A. (2002) Prevalence of Porcine Cysticercosis and Hydatidosis in Slaughtered Animals in Southwestern Zimbabwe: A Retrospective Study. Proceedings of the 11 th Annual Meeting of ENRECA Livestock Helminths Research Project in Eastern and Southern Africa, Lusaka, 6-9 June 2002.

[122] Ngwing, N.A., Poné, J.W., Mbida, M., Pagnah, A.Z., Njakoi, H. and Bilong, C.F. (2012) A Preliminary Analysis of Some Epidemiological Factors Involved in Porcine Cysticercosis in Bafut and Santa Subdivisions, North West Region of Cameroon. Asian Pacific Journal of Tropical Medicine, 5, 814-817. https://doi.org/10.1016/S1995-7645(12)60149-7

[123] Prado-Jean, A., Kanobana, K., Druet-Cabanac, M., Nsengyiumva, G., Dorny, P., Preux, P.M. and Geerts, S. (2007) Combined Use of an Antigen and Antibody Detection Enzyme-Linked Immunosorbent Assay for Cysticercosis as Tools in an Epidemiological Study of Epilepsy in Burundi. Tropical Medicine \& International Health: TM \& IH, 12, 895-901. https://doi.org/10.1111/j.1365-3156.2007.01860.x

[124] Amos, C. (2013) Prevalence of and Soil Transmitted Helminths in Rural Communities of Monze District of Southern Zambia. UNZA Metadata.

[125] Kagira, J.M., Maingi, N., Kanyari, P.W., Githigia, S.M., Ng'ang'a, J.C. and Gachohi, 
J.M. (2010) Seroprevalence of Cysticercus cellulosae and Associated Risk Factors in Free-Range Pigs in Kenya. Journal of Helminthology, 84, 398-403. https://doi.org/10.1017/S0022149X10000076

[126] Garcia, H.H., Gonzalez, A.E., Evans, C.A.W. and Gilman, R.H. (2003) Taenia solium Cysticercosis. The Lancet, 362, 547-556. https://doi.org/10.1016/S0140-6736(03)14117-7

[127] Kanobana, K., Praet, N., Kabwe, C., Dorny, P., Lukanu, P., Madinga, J., Mitashi, P., Verwijs, M., Lutumba, P. and Polman, K. (2011) High Prevalence of Taenia solium Cysticerosis in a Village Community of Bas-Congo, Democratic Republic of Congo. International Journal for Parasitology, 41, 1015-1018. https://doi.org/10.1016/j.ijpara.2011.06.004

[128] Mkupasi, E.M., Ngowi, H.A., Sikasunge, C.S., Leifsson, P.S. and Johansen, M.V. (2015) Distribution and Histopathological Changes Induced by Cysts of Taenia solium in the Brain of Pigs from Tanzania. Journal of Helminthology, 89, 559-564. https://doi.org/10.1017/S0022149X14000418

[129] Millogo, A., Nitiema, P., Carabin, H., Boncoeur-Martel, M.P., Rajshekhar, V., Tarnagda, Z., Praet, N., Dorny, P., Cowan, L., Ganaba, R., et al. (2012) Prevalence of Neurocysticercosis among People with Epilepsy in Rural Areas of Burkina Faso. Epilepsia, 53, 2194-2202. https://doi.org/10.1111/j.1528-1167.2012.03687.x

[130] Nsengiyumva, G., Druet-Cabanac, M., Ramanankandrasana, B., Bouteille, B., Nsizabira, L. and Preux, P.M. (2003) Cysticercosis as a Major Risk Factor for Epilepsy in Burundi, East Africa. Epilepsia, 44, 950-955. https://doi.org/10.1046/j.1528-1157.2003.55302.x

[131] Organization, W.H. (2015) Assembling a Framework for Intensified Control of Taeniasis and Neurocysticercosis Caused by Taenia solium.

[132] Hunter, E., Burton, K., Iqbal, A., Birchall, D., Jackson, M., Rogathe, J., Jusabani, A., Gray, W., Aris, E., Kamuyu, G., et al. (2015) Cysticercosis and Epilepsy in Rural Tanzania: A Community-Based Case-Control and Imaging Study. Tropical Medicine \& International Health: TM \& IH, 20, 1171-1179. https://doi.org/10.1111/tmi.12529

[133] Basem, R.N.A., Sayed, A.S.M., Hussein, A.A.A. and Arafa, M.I. (2010) Occurrence of Taenia solium and Cysticercosis in Man in Egypt. Veterinary World, 3, 57-60.

[134] Edia-Asuke, A.U., Inabo, H.I., Mukaratirwa, S., Umoh, V.J., Whong, C.M., Asuke, S. and Ella, E.E. (2015) Seroprevalence of Human Cysticercosis and Its Associated Risk Factors among Humans in Areas of Kaduna Metropolis, Nigeria. Journal of Infection in Developing Countries, 9, 799-805. https://doi.org/10.3855/jidc.5415

[135] Eke, S.S., Oguniyi, T., Omalu, I.C.J., Otuu, C.A., Udeogu, V.O., Luka, J., Paul, S., Abubakar, N.E. and Ubanwa, E.D. (2014) Prevalence of Human Taeniasis among School Children in Some Selected Primary Schools in Bosso Local Government Area, Minna, Niger State, Nigeria. Ijabr, 6, 80-86.

[136] Ekpo, U.F., Odoemene, S.N., Mafiana, C.F. and Sam-Wobo, S.O. (2008) Helminthiasis and Hygiene Conditions of Schools in Ikenne, Ogun State, Nigeria. PLOS Neglected Tropical Diseases, 2, e146. https://doi.org/10.1371/journal.pntd.0000146

[137] Mogaji, H., Adeniran, A., Fagbenro, M., Olabinke, D., Abe, E. and Ekpo, U. (2016) Prevalence of Human Taeniasis in Odeda Area of Ogun State, Nigeria. International Journal of Tropical Disease \& Health, 17, 1-8. https://doi.org/10.9734/IJTDH/2016/27084

[138] Alarakol, S.P., Joloba, M.L. and Aginya, E.O. (2017) Seroprevalence of Taenia solium Cysticercosis among People with Epilepsy Epileptic Patients in Three Rural 
Districts of Northern Uganda.

[139] Sibongiseni, T.G., James, W.O. and Mary, M.M. (2016) Pig Farming in Rural South Africa: A Case Study of uThukela District in KwaZulu-Natal. Indian Journal of Animal Research, 50, 614-620.

[140] Penrith, M.L., Lopes Pereira, C., Lopes da Silva, M.M., Quembo, C., Nhamusso, A. and Banze, J. (2007) African Swine Fever in Mozambique: Review, Risk Factors and Considerations for Control. Onderstepoort Journal of Veterinary Research, 74, 149-160.

[141] Kagira, J.M., Maingi, N., Kanyari, P.W.N., Githigia, S.M., Nganga, J.C. and Gachohi, J.M. (2009) Characteristics of Pig Trade in Low Income Settings in Busia District, Kenya. Tropical Veterinarian, 26, 1-9.

[142] Stensgaard, A.S., Utzinger, J., Vounatsou, P., Hurlimann, E., Schur, N., Saarnak, C.F., Simoonga, C., Mubita, P., Kabatereine, N.B., Tchuem Tchuente, L.A., et al. (2013) Large-Scale Determinants of Intestinal Schistosomiasis and Intermediate Host Snail Distribution across Africa: Does Climate Matter? Acta Tropica, 128, 378-390. https://doi.org/10.1016/j.actatropica.2011.11.010

[143] Petrus, N.P., Schneider, M.B. and Nepembe, M. (2011) The Constraints and Potentials of Pig Production among Communal Farmers in Etayi Constituency of Namibia. Livestock Research for Rural Development, 23.

[144] Cook, E.A. (2014) Epidemiology of Zoonoses in Slaughterhouse Workers in Western Kenya. PhD Thesis, University of Edinburgh, Edinburgh.

[145] Elliott, I., Jerome, A., Angwafor, S.A., Smith, M.L., Takougang, I., Noh, J., Tsang, V., Wilkins, P., Cockburn, L., Keystone, J., et al. (2013) Epilepsy and Cysticercosis in Northwest Cameroon: A Serological Study. Seizure, 22, 283-286. https://doi.org/10.1016/j.seizure.2013.01.012

[146] Ganaba, R., Praet, N., Carabin, H., Millogo, A., Tarnagda, Z., Dorny, P., Hounton, S., Sow, A., Nitiema, P. and Cowan, L.D. (2011) Factors Associated with the Prevalence of Circulating Antigens to Porcine Cysticercosis in Three Villages of Burkina Faso. PLOS Neglected Tropical Diseases, 5, e927. https://doi.org/10.1371/journal.pntd.0000927

[147] Ngowi, H., Ozbolt, I., Millogo, A., Dermauw, V., Somé, T., Spicer, P., Jervis, L.L., Ganaba, R., Gabriel, S., Dorny, P., et al. (2017) Development of a Health Education Intervention Strategy Using an Implementation Research Method to Control Taeniasis and Cysticercosis in Burkina Faso. Infectious Diseases of Poverty, 6, 95. https://doi.org/10.1186/s40249-017-0308-0

[148] Agbolade, O.M., Agu, N.C., Adesanya, O.O., Odejayi, A.O., Adigun, A.A., Adesanlu, E.B., Ogunleye, F.G., Sodimu, A.O., Adeshina, S.A., Bisiriyu, G.O., et al. (2007) Intestinal Helminthiases and Schistosomiasis among School Children in an Urban Center and Some Rural Communities in Southwest Nigeria. The Korean Journal of Parasitology, 45, 233-238. https://doi.org/10.3347/kjp.2007.45.3.233

[149] Schur, N., Hurlimann, E., Stensgaard, A.S., Chimfwembe, K., Mushinge, G., Simoonga, C., Kabatereine, N.B., Kristensen, T.K., Utzinger, J. and Vounatsou, P. (2013) Spatially Explicit Schistosoma Infection Risk in Eastern Africa Using Bayesian Geostatistical Modelling. Acta Tropicaica, 128, 365-377.

https://doi.org/10.1016/j.actatropica.2011.10.006

[150] Kambashi, B., Picron, P., Boudry, C., Théwis, A., Kiatoko, H. and Bindelle, J. (2014) Smallholder Pig Production Systems along a Periurban-Rural Gradient in the Western Provinces of the Democratic Republic of the Congo. Journal of Agriculture and Rural Development in the Tropics and Subtropics, 115, 9-22. 
[151] Shey-Njila, O., Zoli, P.A., Awah-Ndukum, J., Nguekam, A.E., Byambas, P., Dorny, P., Brandt, J. and Geerts, S. (2003) Porcine Cysticercosis in Village Pigs of North-West Cameroon. Journal of Helminthology, 77, 351-354. https://doi.org/10.1079/JOH2003179

[152] Terefe, A., Shimelis, T., Mengistu, M., Hailu, A. and Erko, B. (2011) Schistosomiasis mansoni and Soil-Transmitted Helminthiasis in Bushulo Village, Southern Ethiopia. Ethiopian Journal of Health Development, 25, 46-50. https://doi.org/10.4314/ejhd.v25i1.69847

[153] Iroyukifujita, H., Eiichiyokoyama, K. and Yoshikawa, M. (2000) Classification and Antihypertensive Activity of Angiotensin I-Converting Enzyme Inhibitory Peptides Derived from Food Proteins. Journal of Food Science, 65, 564-569. https://doi.org/10.1111/j.1365-2621.2000.tb16049.x

[154] Deckers, N. and Dorny, P. (2010) Immunodiagnosis of Taenia solium Taeniosis/Cysticercosis. Trends in Parasitology, 26, 137-144.

https://doi.org/10.1016/j.pt.2009.12.008

[155] Murrell, K.D., Dorny, P., Flisser, A., Geerts, S., Kyvsgaard, N.C. and Mcmanus, D.P. (2005) WHO/FAO/OIE Guidelines for the Surveillance, Prevention and Control of Taeniosis/Cysticercosis.

[156] Cárdenas, G., Valdez, R., Sáenz, B., Bottasso, O., Fragoso, G., Sciutto, E., Romano, M.C. and Fleury, A. (2012) Impact of Taenia solium Neurocysticercosis upon Endocrine Status and Its Relation with Immuno-Inflammatory Parameters. International Journal for Parasitology, 42, 171-176. https://doi.org/10.1016/j.ijpara.2011.11.009

[157] Pena, N., Morales, J., Morales-Montor, J., et al. (2007) Impact of Naturally Acquired Taenia solium Cysticercosis on the Hormonal Levels of Free Ranging Boars. Veterinary Parasitology, 149, 134-137. https://doi.org/10.1016/j.vetpar.2007.07.018

[158] Ngwing, N.A.N., Poné, J.W., Mbida, M., Pagnah, A.Z., Njakoi, H. and Bilong, C.F.B. (2012) A Preliminary Analysis of Some Epidemiological Factors Involved in Porcine Cysticercosis in Bafut and Santa Subdivisions, North West Region of Cameroon. Asian Pacific Journal of Tropical Medicine, 5, 814-817. https://doi.org/10.1016/S1995-7645(12)60149-7

[159] Weka, R.P. and Ikeh, E.I. (2009) Seroprevalence of Cysticercosis and Intestinal Parasitism in Pigs in Jos Metropolis. Journal of Animal and Veterinary Advances, 8, 883-887. https://doi.org/10.3923/javaa.2009.883.887

[160] Fortunato, S., Castagna, B., Monteleone, M.R., Pierro, R., Cringoli, G. and Bruschi, F. (2014) Parasite Prevalence in a Village in Burkina Faso: The Contribution of New Techniques. Journal of Infection in Developing Countries, 8, 670-675. https://doi.org/10.3855/jidc.3660

[161] Balogou, K.A.A., Beketi, K., Belo, M., Kowu, A. and Grunitzky, E.K. (2001) Epidémiologie de l'épilepsie dans la préfecture de Tone au Togo. Epilepsies, 13, 185-189. 